\title{
Stopping, Shaping and Moulding Europe: Two-Level Games, Non-state Actors and the Europeanization of Migration Policies
}

\author{
GEORG MENZ
}

Goldsmiths College, University of London

\begin{abstract}
Europeanization is not only top-down and one-dimensional. National governments play two-level games, encountering non-state actors that seek to shape the national interest positions. Examining migration and asylum policy, a domain not yet subject to extensive scholarly attention, the role of non-state interest groups and their influence, where coalition-building is successful, is highlighted. Empirically, the article explores the genesis of the EU's family reunion, asylum qualification and the labour migration directives. In theoretical terms, the article contributes to the burgeoning literature on Europeanization, while seeking to refine it further and apply it to a somewhat neglected policy domain.
\end{abstract}

\section{Introduction}

Europeanization has emerged as a central concept for analytical approaches to the study of European policy-making. Despite a long-standing scholarly debate and increasingly more sophisticated definitions (Ladrech, 1994; Héritier et al., 2001; Börzel, 2002; Radaelli, 2000, 2003; Schmidt, 2006; Bache, 2008), the term is still often used to denote different aspects of European integration. While most scholars focus on top-down processes involving the "central penetration of national systems of governance' (Olsen, 2002), others employ the term to describe the 'emergence and development at the European level of distinct structures of governance' (Cowles et al., 2001, p. 2). 
'Top-down' Europeanization affects 'member states' policies and political and administrative structures' (Héritier et al., 2001, p. 3), but also institutional rules of the game (Knill and Lehmkuhl, 1999; Cowles et al., 2001; Jordan and Liefferink, 2004) or even identity (Jordan, 2002). Radaelli (2003, p. 30) describes 'processes of (a) construction, (b) diffusion, and (c) institutionalization of formal and informal rules, procedures, policy paradigms, styles, "ways of doing things", and shared beliefs and norms', while helpfully suggesting four categories that capture the impact at the national level: inertia, absorption, transformation, retrenchment.

However, Europeanization constitutes a 'shaped process, not a passively encountered process' (Wallace, 2000, p. 370). It is commonly neglected that it is also 'circular, rather than unidirectional, and cyclical rather than one off' (Goetz, 2002, p. 4). Rather than simply conceptualizing Europeanization as a process of imposed implementation or 'learning to cope with Europe', it is both more appropriate and fruitful to conceive of it as the emergence of multiple arenas of governance (Andersen and Eliassen, 1993; Marks and Hooghe, 2004), entailing both top-down and bottomup processes, unleashing potential for new and dynamic games played out in several arenas, often concurrently (Putnam, 1988; Snyder, 1977). This may involve "new opportunities to exit from domestic constraints, either to promote certain policies, or to veto others, or to secure information advantages' (Goetz and Hix, 2001, p. 10). Börzel and Risse (2000) suggested the concepts of 'upload' and 'download' that have not been widely taken up in further scholarly contributions. While these terms are heuristically useful, they rather infelicitously imply a degree of automaticity that is rarely present and denies the reality of protracted political battles.

This article argues that Europeanization needs to be (re)considered as an often heavily embattled two-way process, spawning several institutional arenas. In empirical terms, it examines the genesis of three pivotal European Union migration and asylum directives on family reunion, asylum qualification and economic migration. How does the two-level game of Europeanization unfold? When and how do non-state or governmental actors succeed in shaping EU-level policy outcomes? Policy-making at the national level involves non-state actors such as non-governmental organizations (NGOs) and employer associations, lobbying in order to influence national interest positions. At the European level, governments may either attempt to upload their own national position as a blueprint for future European regulation, bargain for exceptions that safeguard the national status quo, or seek to delay or even impede European decision-making while crucial domestic negotiation games play out. 
The article examines the dynamics of all three strategies, arguing that non-state actors need to build robust coalitions in order to shape national interest positions. Similarly, governments need to construct coalitions in the Council of Ministers to upload policy, safeguard national arrangements or impede top-down Europeanization. Thus, the Austrian, German and Dutch governments succeeded in securing national restrictive arrangements regarding family reunion procedures. In constructing an alliance with the Green Party, part of the government coalition at the time, German NGOs managed to influence the national positions, eventually securing a concession leading to the acceptance of asylum seekers persecuted by non-state actors. Finally, the German and Austrian governments, influenced by sceptical employers, successfully blocked a comprehensive EU labour migration directive.

The article draws on the analysis of legislation, primary and secondary literature and elite interviews. ${ }^{1}$ It is organized as follows. Section I discusses the findings of the Europeanization literature and demonstrates how existing accounts can be modified by considering the dynamics of two-level games. Sections II, III and IV are empirical and explore the politics of the three directives. A conclusion succinctly summarizes the key findings and main theoretical contribution.

\section{A Europeanized Policy Domain: The Logics of Asylum and Migration Policy-Making}

Notwithstanding efforts to engage in 'venue shopping' (Guiraudon, 2000) and preferring the more amiable setting of the Council of Ministers to 'escape' the confines of a more contested national arena where the media, courts, labour market interests associations and humanitarian NGOs seek to influence the national position, governmental actors are engaged in two types of games. On one level, they negotiate the contours of new EU regulation with other governmental actors in the Council of Ministers, while on a second level, they face domestic non-governmental actors. One crucial weakness in current Europeanization debates concerns temporality and ontology: a direct sequence is commonly assumed. Yet there may be temporal overlap or even synchronicity. The second process may precede the first, whereby national actors attempt to shape the agenda, employing their own national regulatory model as a template for future European regulation (Geddes and Guiraudon, 2004).

\footnotetext{
${ }^{1}$ For reasons of space constraints, only directly cited interviews will be referenced. As part of a larger research project, an additional 30 interviews were carried out with representatives of government officials, employer associations and NGOs in six European countries.
} 
The relatively recent nature of Europeanization in this policy domain may explain the limited scholarly attention (Vink, 2005; Graziano and Vink, 2007; Faist and Ette, 2007). Taking Europeanization seriously as a promising research agenda, rather than a mere fad, the scope of analytical inquiry needs to be broadened, which inevitably involves 'messy' interactive processes, spilling over and being played out in several arenas. Public policy in particular does not simply emerge out of thin air at the EU level, but is generally the mutated offspring of national initiatives, heritage, patterns of regulation and governance (Geddes and Guiraudon, 2004). In the migration policy domain, the Committee on Immigration and Asylum (CIA) is an important consultation forum where Commission officials and Member State representatives liaise to exchange positions, ideas and interests, thus assuring that Commission draft policy is well informed of potential veto positions and veto players. ${ }^{2}$

There is no automatism in the increase in EU competence; the European arena relies on the interaction of actors that possess a strong interest in moulding policy-making according to their preferences. National governmental actors united in the Council of Ministers may actively shape deliberations at the EU level to influence the eventual outcome according to national preferences. This aspect of Europeanization remains somewhat bereft of scholarly attention. Modifying Radaelli's (2003, p. 30) definition of top-down Europeanization, and building on Börzel's (2002, p. 194) useful concepts of 'pace-setting', 'foot-dragging' and 'fence-sitting', an additional aspect of Europeanization can thus be defined as:

Processes at the EU level that (a) aim to influence other governmental actors, (b) diffuse one's own agenda and preferences to other actors, and (c) colour, shape, modify, influence or even dominate to varying degrees emerging EU formal and informal rules, procedures, policy paradigms, styles and shared beliefs and norms by making use of formal and informal EU venues, themselves influenced by national patterns and traditions of regulation in the relevant policy domains and the interaction of national governmental actors and non-governmental actors.

It appears fruitful to borrow from the insights on the emergence of national interest positions and coalitions in the international relations literature. Exposing the notion of national interest to careful scrutiny and disaggregating it, the role of domestic non-governmental actors engaged in various forms of advocacy coalitions as domestic sources of governmental preferences emerges as a clear and central theme (Gourevitch, 1978, 1996; Rogowski, 1989; Keohane and Milner, 1996; Milner, 1997). Helen Milner (1992, p. 494)

${ }^{2}$ Interview with senior officials at the DG Justice, Freedom and Security, Brussels (henceforth EU-COM-1). 
argued that the "national interest will be the sum of the preferences of different interest groups as weighted by their access to policy-making institutions'.

As a highly influential study of the nexus between the domestic and international politics highlighted, policy-makers are involved in multi-level games (Putnam 1988, p. 434):

[A]t the national level, domestic groups pursue their interests by pressuring the government to adopt favourable policies, and politicians seek power by constructing coalitions among those groups. At the international level, national governments seek to maximize their own ability to satisfy domestic pressures, while minimizing the adverse consequences of foreign developments.

The relatively slow and contested progress in creating European migration and asylum policy (Messina, 2007; Menz, 2008) is related to national governments holding a vested interest in the maintenance of established regulatory patterns. Policy blueprints that successfully imprint EU policy permit first-mover advantages and minimal transaction costs (Héritier, 1996). Such benefits shape decision-making strategies, especially as migration regulation is commonly influenced by established national regulatory patterns and approaches, examined in great detail in the comparative migration literature (Uçarer and Puchala, 1997; Cornelius et al., 2004), which are commonly coloured by locked-in past decisions that create trajectories of path dependency (Hansen, 2002) that are politically very difficult and costly to modify.

The 'first-mover advantage' (Héritier, 1996; Börzel, 2002) may thus motivate governmental actors to ensure that their propositions provide the basis for future EU regulation. However, such a process needs to involve coalitionbuilding, given the requirement to secure a qualified majority, or indeed unanimity, in the Council of Ministers. Where domestic actors sense an opportunity to shape not only the position of the corresponding national government, but also indirectly EU regulation, their advocacy efforts will be pronounced. As Börzel and Risse (2003, p. 62) mention, it is very unlikely and extremely difficult for any one actor or coalition to be successful all the time in agenda-setting. Since migration policy is a highly politicized policy domain with links to citizenship, access to labour markets and systems of social policy, and given extremely divergent legacies of migration regulation, Börzel and Risse's 'goodness of fit' concept, developed drawing upon environmental policy, appears less helpful then Radaelli's (2000, 2003) emphasis on intervening variables, notably veto players, technocratic capture potential and advocacy coalitions. These insights are applied by the few existing 
studies of Europeanized migration policy-making (Fischer et al., 2002; Faist and Ette, 2007).

Though governments try to buffer attempts by non-state actors to lobby and influence migration policy, such actors nevertheless will play a role in affecting 'what determines the responses, adaptability and robustness of domestic institutions, including their ability to ignore, buffer, redefine or exploit external European-level pressures' (Olsen, 2002, p. 933). Knill and Lehmkuhl (2002, pp. 260ff.) emphasize that changes in the national regulatory environment due to Europeanization are most likely to occur if there is no domestic dominant actor coalition. Interest groups may be present and potent, yet not interested or even adamantly opposed to European regulation.

This article focuses on two sets of domestic actors that attempt to influence national negotiation positions. First, employer associations will seek to shape economic migration policies. However, some may prefer national migration to European schemes they cannot as easily influence. Similarly, humanitarian NGOs endeavour to influence asylum and humanitarian migration policy such as family reunion. They may consider the national arena preferable to the more opaque European level. Actors may anticipate battles at the EU level they would prefer to avoid and thus seek to maintain control over the arena. In the migration literature the role of non-state actors is commonly neglected. Scholarly accounts suggest that the influence of humanitarian interest groups (Favell, 1998; Geddes, 2000) is limited at best, while employer associations have received no significant coverage thus far.

The 1999 Tampere Council served as the cornerstone for recent EU migration policy design. Article 20 of the final communiqué sets out the "need for approximation of national legislations on the conditions for admission and residence of third-country nationals, based on a shared assessment of the economic and demographic developments within the Union, as well as the situation in the countries of origin. It requests to this end rapid decisions by the Council, on the basis of proposals by the Commission'. Despite sustained Commission activity henceforth, responses from Member State representatives in the Council were very mixed, including apathy and even significant antipathy. The following three sections analyse the genesis of three key directives - namely the family reunion directive, the asylum 'qualification' directive and the ultimately frustrated attempt to create a single labour migration directive.

Though Member States and the Commission jointly shared the right to propose directives until 2004, the vast majority of proposals originated with the latter, with only a few exceptions such as Member State initiatives on joint deportation measures. After the end of this transition period, the Council decided on 22 December 2004 (2004/927/EC) to act by qualified majority 
voting, as opposed to unanimous decision-making, on initiatives either covered by Article 62.1.2.a and 3 or Article 63.2.b. and 3.b of the EC Treaty. The former cover internal border controls and the intra-EU freedom of mobility for third-country nationals, while the latter concern asylum seekers and undocumented migrants, along with the presence and deportation of undocumented residents. However, unanimous decision-making was maintained in other areas of Title IV - most importantly regarding labour migration.

\section{The Family Reunification Directive}

Family reunion is the single largest access channel for legal immigrants (Messina, 2007). Particular resistance to European activity came from Germany, Austria and the Netherlands (Table 1). All three governments sought to safeguard existing national arrangements, avoiding administratively and politically costly adaptation costs. Labour market interest associations generally did not become active on this issue. ${ }^{3}$ By contrast, NGOs were following the elaboration closely and, in the German case, communicated their grievances to the Ministry of Interior Affairs. ${ }^{4}$ These lobbying efforts were unsuccessful initially, as the German government sought to secure room for manoeuvre in the elaboration of the national regulation by securing a European regulation permitting such national exception. Both the Dutch and Austrian governments attempted to safeguard existing restrictive national regulations against European 'interference'. In both countries, NGOs attempted, but failed, to shape the national agenda. In Germany, however, the NGO camp did at least try to build a coalition with the Green Party - a member of the government coalition - in seeking to secure a higher age for minors benefiting from family reunion nationally. In the meantime, the German government managed to obtain European permission to impose an age as low as 12 at the European level. There, the Dutch-Austrian-German trio successfully built a blocking coalition that secured national exception regarding the age of minors and spouses and, in the Austrian case, regulations concerning health insurance and adequate housing. At this level, an NGO coalition, co-ordinated by French GISTI, marshalled resistance to these exceptions, building a coalition with the European Parliament based on a

\footnotetext{
${ }^{3}$ Interview with official at employer association BDA, Berlin (henceforth DE-BUS-1).

${ }^{4}$ Interview with senior official at German humanitarian NGO, Berlin (henceforth DE-NGO-1); Interview with senior official at German humanitarian NGO, Berlin (henceforth DE-NGO-2); Interview with official at French humanitarian NGO, Paris (henceforth FR-NGO-1); Interview with official at French humanitarian NGO, Paris (henceforth FR-NGO-2); Interview with official at French humanitarian NGO, Paris (henceforth FR-NGO-3); ProAsyl (2004); Amnesty International et al. (2007).
} 


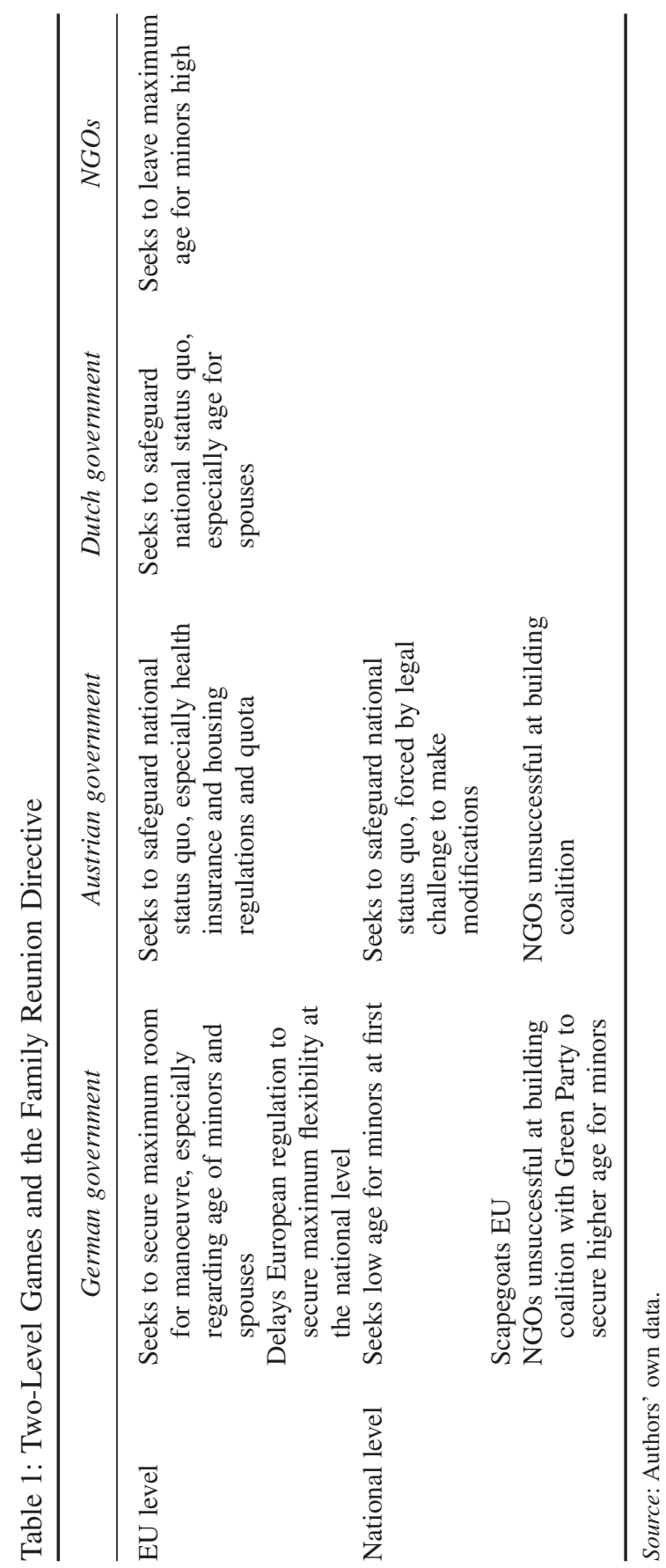


procedural mistake committed by the Commission. Ultimately, this action resulted in an unsuccessful lawsuit at the European Court of Justice (ECJ).

The Commission produced a draft directive on the issue as early as 1 December 1999 (COM (1999) 638). It was considered by the European Parliament (EP) under the consultation procedure. The EP committee issued its report in July 2000 ('Watson Report', A5-201/2000 of 17 July 2000). On 6 September 2000, the EP voted on the directive, suggesting minor liberal modifications, but supporting the main provisions. The reception in the Council was frosty. Discussing the matter on four different occasions over a two-year period (2 December 1999, May 2000, 28-29 May and 27-28 September 2001) significant opposition surfaced early on and no consensus on alternative proposals emerged. In the meantime, the Commission produced a modified directive on 10 October 2000 (see COM (2000) 624 final), incorporating EP suggestions. Member States asked the Commission during the Laeken Council meeting of 14-15 December 2001 to produce a revised directive reflective of previously expressed opinions (Groenendijk, 2004a; Schibel, 2004).

Discussions resumed in the context of the working party on migration and expulsion on 8 and 26 July, hurried along by the June 2002 Seville European Council decision to agree on a directive by June 2003. These discussions proceeded on the basis of a third version of the directive, amended on 3 May 2002 (COM (2002) 225 final), eventually leading to the adoption of directive 2003/86/EC on 22 September 2003. In the meantime, the Commission committed a procedural faux pas. ${ }^{5}$ Substantially, the EP was critical of the abrogation on the issue of the age of children, permitting Member States to end family reunion rights to children above the age of 15 and to restrict them to children older than 12 , thus allegedly violating the right to private and family rights, enshrined in Article 8 of the European Charter of Human Rights.

Several NGOs concurred. Under the able stewardship of French group GISTI (Groupe d'information et de soutien des immigrés), combining resources with the pan-European umbrella association COORDEUROP (European Co-ordination for Foreigners' Right to Family Life), sympathetic MEPs were identified, contacted and lobbied in favour of submitting a formal complaint (COORDEUROP, 2003a, b). This proved successful and on 22 December 2003 the EP used the new procedure introduced in the Nice Treaty (Article 230, para. 2) to lodge a complaint based on an alleged violation of the

\footnotetext{
${ }^{5}$ On 22 December 2003, the EP brought an action for annulment before the ECJ, as in violation of Article 67 of the EC Treaty the EP had not been properly consulted (ECJ case C-540/03, O.J. 2004/C47/35). The Court did not accept this claim. In substantive terms, it did not consider the critical question of age to constitute undue discrimination (ECJ C540/03, 74, cited in Franz, 2006, p. 52).
} 
right to family life and the principle of non-discrimination (Article 6, para. 2) (OJ2004/C47/35 of 21 February 2004). However, the ECJ rejected the complaint (ECJ C540/03).

In Germany, the age of minors eligible for family reunion was emerging as an unlikely yet significant point of contention during the concurrent domestic discussions of the new immigration law (FAZ, 7 February 2002; Berliner Zeitung, 1 February 2002, 10 February 2003). German humanitarian NGOs ${ }^{6}$ sought allies among the Green Party, part of the coalition government. However, the German Ministry of Interior, while receiving a wide array of NGOs for informal consultations, ${ }^{7}$ did not bulge on this question initially. Amnesty International played 'a pivotal role" ${ }^{8}$ on the issue, but not all other NGOs were equally committed. The Ministry of Interior exploited this substantial weakness domestically, while simultaneously seeking to achieve a restrictive EU regulation so as to maximize room for manoeuvre regarding the national regulation, either leaving the age at 16 or reducing it to $12 .{ }^{9}$ In domestic discussions, the Ministry used the EU as a political scapegoat to justify a more restrictive stance (Groenendijk, 2004b).

At the European level, it received assistance from its Austrian homologue (OJ 120222/01 of 24 September 2001). The Austrian government was keen to preserve the stringent national legal status quo, including quotas, limiting annual family reunion flows to 5,490, set by the Ministry of Interior Affairs in consultation with the Länder governments. In addition, stringent regulations placed considerable burden of proof on applicants regarding income, living situation and health insurance of 'locally customary' (ortsüblich) standard (Der Standard, 18 December 2003; Evrensel and Höbart, 2004). A legal challenge by the Austrian Constitutional Court spawned minor modifications (Fremdengesetznovelle) in 2002. The court ruled the fairly restrictive administrative procedures of this quota unconstitutional as well as subsuming family reunion privileges granted for humanitarian reasons under this annual quota (VFGH G119/03 ua 17013 of 8 October 2003; Der Standard, 9 October 2003).

However, the Austrian Ministry of Interior Affairs played the two-level game successfully, securing the safeguarding of national regulations at the European level, while ignoring domestic protests from the NGO camp and the opposition parties who failed to build a coalition. It was adamant in watering down the original Commission proposal to insert the possibility of two- to

\footnotetext{
${ }^{6}$ DE-NGO-1; DE-NGO-2.

${ }^{7}$ Interview with senior official at German Ministry of Interior Affairs, Berlin (henceforth DE-GOV-1); DE-NGO-1.

${ }^{8}$ DE-NGO-1.

${ }^{9}$ DE-GOV-1; Berliner Zeitung, 10 February 2003.
} 
three-year waiting periods for applicants for family reunion, thus permitting the safeguarding of the national quota system in principle. A second judiciary challenge from the Constitutional Court (Evrensel and Höbart, 2004, p. 85; Biffl, 2005) led to modifications, permitting migrants who had entered Austria prior to 1 January 1998 to bring in children up to the age of 18, as opposed to the general maximum age of 15 . These changes were to lead to the 7 July 2005 Residency Law (Niederlassungs- und Aufenthaltsrecht, 2005), but most of the administrative regulations had been safeguarded against EU-induced change.

A Dutch-German-Austrian alliance successfully secured national room for manoeuvre to impose mandatory attendance requirements for integration and language classes (OJ 14727/02) as a set condition even prior to arrival. The German and Dutch ministers also jointly secured the possibility of imposing minimum ages for spouses benefiting from family reunion during the Council meeting on 27 February 2003, ostensibly to reduce forced marriages. The Dutch minister was particularly active as such EU regulation permitted honouring the coalition agreement with the far-right Pim Fortuyn movement (Groenendijk, 2004b, p. 127). The Germans sought to extend the national room for manoeuvre in the ongoing reform of national migration law, permitting highly visible political action to placate the political right, while paradoxically scapegoating the EU for assuming a restrictive stance. Despite some lobbying activity, the German NGO camp was not united on this point and failed to influence the government's position. ${ }^{10}$

The need to accommodate the apparent resistance to some of the Commission's ideas pervades the revised 2002 (225) version. This is acknowledged as leaving 'room for manoeuvre in national legislation' and 'limited cases of exceptions' (para. 2.1). It concerns particularly the contested issue of the age of children, of crucial import to the Austrian and German delegations who threatened to block any further progress if no such concession was made. The final version of the directive imposed the respective national legal age of maturity as the maximum age for minors eligible for family reunion, along with the requirement for children to be unmarried. It permitted Member States to regulate children above the age of 12 in more detail - for example, requiring them to meet national integration criteria such as language examinations.

In a similar vein, the directive only makes mandatory provisions for the spouse and minor children, while the regulation of the status of other relatives in the ascending line, children over whom custody is shared, dependent adult children and unmarried (including same sex) partners is left up to the Member

${ }^{10}$ DE-NGO-1; DE-NGO-2; ProAsyl (2004); Amnesty International et al. (2007). 
States if they so wish (Franz, 2006, p. 50). Reservations about unmarried partners came from Spain, Greece and Portugal. Member States may, but do not have to, impose age limits on spouses to prevent forced marriages. They may continue the previous practice of examining applicants still located outside the country, as the directive applies regardless of physical location of the applicant.

Another heavily contested issue at the European level concerned the requirements for lodging an application. There was some debate as to whether substantive requirements should be made in addition to proving a certain level of income. The Austrian delegation demanded health examinations and language requirements, and also queried how this threshold should be determined and whether it should be re-examined after a certain amount of time, moving beyond even the restrictive national regulation. However, the Austrians failed to find support for this attempt at agenda-setting, which was of no interest to the German delegation ${ }^{11}$ or any other. ${ }^{12}$ The compromise line adopted by the Commission rendered the requirement of adequate housing and health insurance optional and found a threshold income level as the lowest common denominator position just above the minimum level of social assistance. With this regulation, found in Article 7 of the directive, the Austrian status quo was safeguarded, but the more restrictive suggestions had not been incorporated into new European regulation due to the failed attempt at coalition-building.

The next contested point, concerning the amount of time an immigrant has to spend in a Member State before becoming eligible for family reunion, increased from one to two years between the first draft directive and the final version. Member States were granted the right to impose waiting periods of up to three years. This safeguarded the Austrian quota practice in principle and addressed the Austrian delegation's repeated concerns over the receiving state's 'absorption capacity'.

The modified directive also contained significantly less progressive clauses regarding immigrants' rights. In the initial 1999 draft, the Commission sought to align the rights of immigrants covered by this directive to those of EU citizens with respect to access to the labour market and education. This suggestion came under fierce criticism, especially from Austria, Germany and the Netherlands (Hauschild, 2003). Subsequently, it was proposed to align the rights of the applicant's family only with those enjoyed by the former. Decoupling the rights of the family from those of the applicant proved similarly thorny. The Commission eventually addressed this point by

\footnotetext{
${ }^{11}$ DE-GOV-1.

${ }^{12}$ Interview with senior official at French Ministry of Interior Affairs, Paris (henceforth FR-GOV-1). 
setting a relatively high minimum residence requirement of five years, before 'sponsored' family members could obtain independent residency permits (Article 15).

Due to the major resistance encountered, the difference between the first 1999 draft and the final result, which had to be adopted into national law by 3 October 2005, is stark. Revealingly, the directive no longer contains any right to family reunion as such, but instead merely seeks to 'determine the conditions in which the right to family reunion may [sic] be exercised' (Article 1). The so-called 'standstill' principle establishes that the new and arguably somewhat less rigorous rules on family reunification implemented in Italy, Belgium and Denmark in 2002 could not be modified retroactively to offer an inferior level of protection. However, the concurrence between policy-making at the national and EU levels, with developments under way in Portugal, Austria and Germany, proved important, especially as the latter two countries pushed for relatively restrictive rules that would require any 'softening' of their own policies. Substantial scepticism also came from the Dutch.

On this issue, the national delegations in the Council of Ministers could proceed without significant input by labour market interest associations who considered this issue immaterial to their interests. ${ }^{13}$ By contrast, national humanitarian NGOs did attempt to exercise influence, using traditional forms of lobbying, especially in the particularly restrictively minded case of Germany, and assisting and supporting a legal challenge lodged by the EP. Ultimately, however, due to internal ideational divergences and lack of successful attempts to construct access channels to governments, these lobbying efforts had relatively limited impact. Mounting the legal challenge through the COOREUROP umbrella association proved possible because there was general disquiet on the part of NGOs over the ever more restrictive contours of the directive and the maximum age for children proved a symbolically important rallying point.

\section{The Asylum Qualification Directive}

The first draft of the qualification directive was presented by the Commission on 12 September 2001 (2001/510 final). It was forwarded to the EP under the consultation procedure. The EP approved the draft in a single reading on 22 October 2002, suggesting a number of amendments that were all subsequently completely ignored. The Council assumed a reserved stance towards this draft proposal. Negotiations extended over nearly 18 months, with

\footnotetext{
${ }^{13}$ Interview with senior official at European Trade Union Congress, Brussels (henceforth EU-UNI-1); Email interview with senior official at UNICE/BusinessEurope, Brussels (henceforth EU-BUS-1).
} 
meetings on 15 October 2002, 28 November, 27 February 2003, 8 May 2003 and 19 February 2004. Political agreement was finally reached on 30 March, and the directive was formally adopted on 29 April 2004. The United Kingdom and Ireland had agreed to 'opt in', while Denmark stayed out.

There were at least three major lines of conflict. First, the issue of exclusion and revocation of refugee status incited considerable controversy. Article 12 specifies the grounds for exclusion, broadly in line with the Geneva Convention. Thus, individuals that have committed war crimes or acts 'contrary to the purposes and principles of the United Nations' can be excluded. The original provision for cessation of refugee status placing the burden of proof with the Member State was subsequently deleted in the final version of the directive.

Second, there were differences regarding the rights awarded to beneficiaries of subsidiary protection. This relatively new category had been used in practice by a number of European authorities, but it lacked a clear basis in international law and was seen by critics as a deliberate attempt to avoid the bestowal of refugee status guaranteed in the Geneva Convention. Not all Member States were prepared to concede formal rights (or at least not particularly expansive rights) and associated pecuniary benefits to this category. This conflict reflects national practices to use the absolute level and even the form (vouchers, etc.) of welfare transfer payments as a mechanism to 'deter' applicants by reducing payment and introducing complicated and difficultto-negotiate payment-in-kind schemes, as is the case in Germany and the UK. Other Member States had no or only rudimentary previous regulation governing eligibility for welfare transfer payments by refuges and asylum seekers (for example, Poland, Italy, Ireland). The difficulty of attaining consensus on this point is reflected in para. 34 of the preamble, which defines "core benefits' as constituting 'minimum income support, assistance in the case of illness, pregnancy and parental assistance', but immediately modifies them by making them dependent on the extent to which they 'are granted to nationals according to [...] legislation'. Beyond this core, the 'modalities and detail of the provision of core benefits [...] should be determined by national law'. Indeed, Article 28 explicitly permits Member States to limit the provision of benefits to beneficiaries of this subsidiary protection to this minimal core.

Third, substantial national opposition came yet again from Germany. The German delegation was particularly concerned about two issues: labour market access rights for beneficiaries of subsidiary protection, and recognition of persecution by non-state actors as legitimate legal basis for asylum. While a consensus on the general thrust of the directive was established by June 2003, the German government refused to give in on these two issues until the labour market access question was resolved in its favour and the 
Table 2: Two-Level Games and the Asylum Qualification Directive

\begin{tabular}{|c|c|c|c|}
\hline & German government & $\mathrm{NGOs}$ & Employers \\
\hline EU level & $\begin{array}{l}\text { Seeks to secure restrictive } \\
\text { stance regarding labour } \\
\text { market access for } \\
\text { beneficiaries of } \\
\text { subsidiary forms of } \\
\text { protection } \\
\text { Seeks to delay European } \\
\text { regulation regarding } \\
\text { the acceptance of } \\
\text { persecution by } \\
\text { non-state actors to } \\
\text { secure maximum } \\
\text { flexibility at the } \\
\text { national level }\end{array}$ & & \\
\hline National level & $\begin{array}{l}\text { Seeks to secure } \\
\text { maintenance of status } \\
\text { quo at first; later } \\
\text { accepts lobbying } \\
\text { demands by NGOs/ } \\
\text { Greens and employers }\end{array}$ & $\begin{array}{l}\text { Successful at building } \\
\text { coalition with Green } \\
\text { Party to secure } \\
\text { recognition of } \\
\text { persecution by } \\
\text { non-state actors }\end{array}$ & $\begin{array}{l}\text { Ultimately successful } \\
\text { at lobbying against } \\
\text { labour market } \\
\text { access rights for } \\
\text { political refugees }\end{array}$ \\
\hline
\end{tabular}

Source: Authors' own data.

recognition of persecution by non-state actors had been newly introduced into the reformed domestic law as part of domestic bargaining.

At the national level, the German government faced two vociferous and well-organized lobbying coalitions (Table 2). First, employer association BDA, though active in lobbying for more liberal labour migration regulation, was critical of permitting labour market access to political refugees. Second, NGOs sought to liberalize national legislation to recognize persecution by non-state actors as a basis for awarding refugee status. The German government delayed negotiations at the European level, but was unable to find allies there to upload German regulations. Faced with powerful and skilful domestic lobbying groups, the government eventually conceded on both issues and secured an abrogation regarding the issue of labour market access for refugees.

German employers were interested in highly skilled economic migrants, but not in what they perceived to be predominantly low-skill political refugees. Permitting labour market access to these groups of migrants was seen as 'contributing to unemployment', bringing in 'unneeded low-skill employees' and contributing to a deterioration of the political climate for lobbying for 
highly skilled migrants. ${ }^{14}$ The government was sympathetic to this position, not least because labour market access also implied more generous welfare payments for unemployed refugees. Prior to the major 2004 reforms of German immigration legislation, persecution by non-state actors was not recognized as grounds for political asylum, somewhat of an anomaly by international comparison (Duchrow, 2004).

The employers did not become active on this issue, but German NGOs had been lobbying the government for quite a while to modify legislation as part of the major immigration legislation reform. ${ }^{15}$ This position was shared within the NGO community, which facilitated maintaining a common position vis-à-vis the Ministry of Interior during hearings and informal rounds of consultation. In addition, the NGOs successfully built a coalition with the Green Party. Though seemingly a minor detail, it emerged as one of the points of contention in the domestic arena, where the conservative CDU/CSU parties rallied against an allegedly excessively liberal immigration reform (Berliner Zeitung, 1 February 2002). Referring to the allegedly undue influence of the Green Party on the draft legislation, conservative Bavarian Minister of Interior Beckstein demanded that 'much Green [influence] needs to go out and much more Black [conservative influence] needs to go in' (Berliner Zeitung, 10 February 2003). The internal consistency and united stance of the NGOs on this issue, its cohesion and successful liaisons with the Green Party ultimately changed the position of the initially highly sceptical Minister of the Interior. ${ }^{16}$ The comparatively well-organized and well-funded NGO Amnesty International took particular interest and was active in lobbying and networking, while other NGOs then joined in. ${ }^{17}$

The German government once again successfully played a two-level game that delayed stringent European regulation until a domestic compromise had been found which precipitated EU-induced change. These delays were all the more remarkable as the particularity of the German stance on this point meant that no allies could be found in the Council as other Member States displayed little appetite for permitting the uploading of the German regulation to the European level which would have implied adaptation costs.

The final result of the deliberations (2004/83/EC) sets forth minimum standards for the qualification of either non-EU citizens or stateless persons as refugees or beneficiaries of subsidiary protection and defines the minimum levels of rights and benefits associated with both categories. In most sections it does not venture much beyond the status quo in established countries of

\footnotetext{
${ }^{14}$ DE-BUS-1.

${ }^{15}$ Amnesty International (2002); UNHCR (2002); Duchrow (2004); DE-NGO-1; DE-NGO-2.

${ }^{16}$ DE-GOV-1; Green (2004).

${ }^{17}$ Amnesty International (2002); DE-NGO-1; DE-GOV-1.
} 
immigration. Though recognition of persecution by non-state actors is now recognized (Article 6.b. and c.), this is counteracted by defining non-state authorities such as UN peacekeeping forces as 'actors of protection', despite the mixed record of this concept in practice. In fact, the presence of 'internal protection' may be grounds for rejection, even 'notwithstanding technical obstacles to return to the country of origin' (Article 8). In general, the final directive represents a much more restrictive document than the initial draft.

The German government did not want to be obliged to be liable for benefit payments, which may have arisen by granting labour market access to refugees and especially beneficiaries of subsidiary protection. This position, though particular, elicited enough passive sympathy from other delegations to ensure that the German status quo was safeguarded. This dilution regarding individuals with subsidiary protection permits taking into account 'the situation of the labour market' when granting work permits and doing so for an undefined 'limited period of time [...] in accordance with national law' (Article 26). With limited enthusiasm over the German approach elsewhere in the Council, the delegation was content with securing a European regulation permitting the safeguarding of the national status quo. Here, as with respect to the notion of persecution by non-state actors, the delegation could not successfully suggest the national regulation pattern as a blueprint. On the latter issue, unfolding events in the national arena led it to change its stance at the EU level. Nevertheless, European negotiations were slowed down to ensure that top-down Europeanization would be delayed and muted in its impact.

\section{The Labour Migration Directive}

The Commission's initiative to create the contours of actively managed labour migration regulation encountered fierce resistance from the Member States. In 2000, it endeavoured to create common criteria for admitting third-country nationals, both self-employed and regular employees. More radical was the principle of creating a single common application procedure that would permit applicants to obtain a combined title, encompassing both residence and work permit. It was hoped that this superimposed EU pathway might in the long term supersede or at least streamline national procedures. Member States were to be permitted to limit admission temporarily or permanently (Article 26 of the 2001 draft directive) or even operate sectorspecific national recruitment schemes, though forced to justify such schemes through the demonstration of exceptional circumstances (Article 6). 
A draft directive on 'the conditions of entry and residence of third-country nationals for the purpose of paid employment and self-employed activities' was issued on 11 July 2001 and transmitted to the Council on 5 September as well as to the EP for consultation. It contained relatively detailed procedures for labour migrant recruitment, based on an individual examination by Member State authorities, taking into account the state of the labour market (Articles 5 and 6). The permit was to be sector-specific (Article 8) and could be revoked if the holder was out of work for more than three months during the first year of residence (Article 9). Member States could also set income limits (Article 6). The initial permit was to be issued for a period to be determined by the Member States, but up to a maximum of three years, with the possibility of an extension by another three years.

The EP issued its opinion on 12 February 2003. The Council was not favourably inclined. The most vocal opponents to this directive were Germany and Austria, while the French delegation was opposed to any quota system (Table 3). The German government sought to retain maximum flexibility for the contours of national economic migration regulation. The Italian delegation suggested its own quid pro quo quota system as a blueprint for economic migration regulation, yet failed to secure sufficient support in the Council. At the EU level, employers opposed a universal directive, while employers at the national level, especially in Germany, opposed decisionmaking power over this crucial domain transferring to Brussels. They were anxious about the limited lobbying power they could marshal there as opposed to the more amiable setting in Berlin.

Both the German and Austrian governments openly questioned the Commission's competence in this area, arguing that Article 63.3 of the Amsterdam Treaty calling for common regulations on 'conditions of entry and residence' did not cover this sensitive point. The more substantial concern arose out of potential limitations on the design of German high-skill migration schemes in the making in mid-2002. Though the identity of national delegations making comments during deliberations is deliberately obscured in the Council documents (Council Doc. 9862/02 of 8 July 2002 and $7557 / 02$ of 10 June 2002), the German hostility becomes obvious in repeated references to 'the new immigration law' being potentially affected. The French government was also strongly sceptical of Commission activity in this field, voicing its concerns that the principle of subsidiarity was being violated (Sénat, 2005).

A position paper by European employer association UNICE indicates that both MEDEF and BDA do not see any 'substantial visible added value in a common EU framework' (UNICE, 2005). Austrian employers WK shared this scepticism. The summary of national preferences reveals antipathy towards 


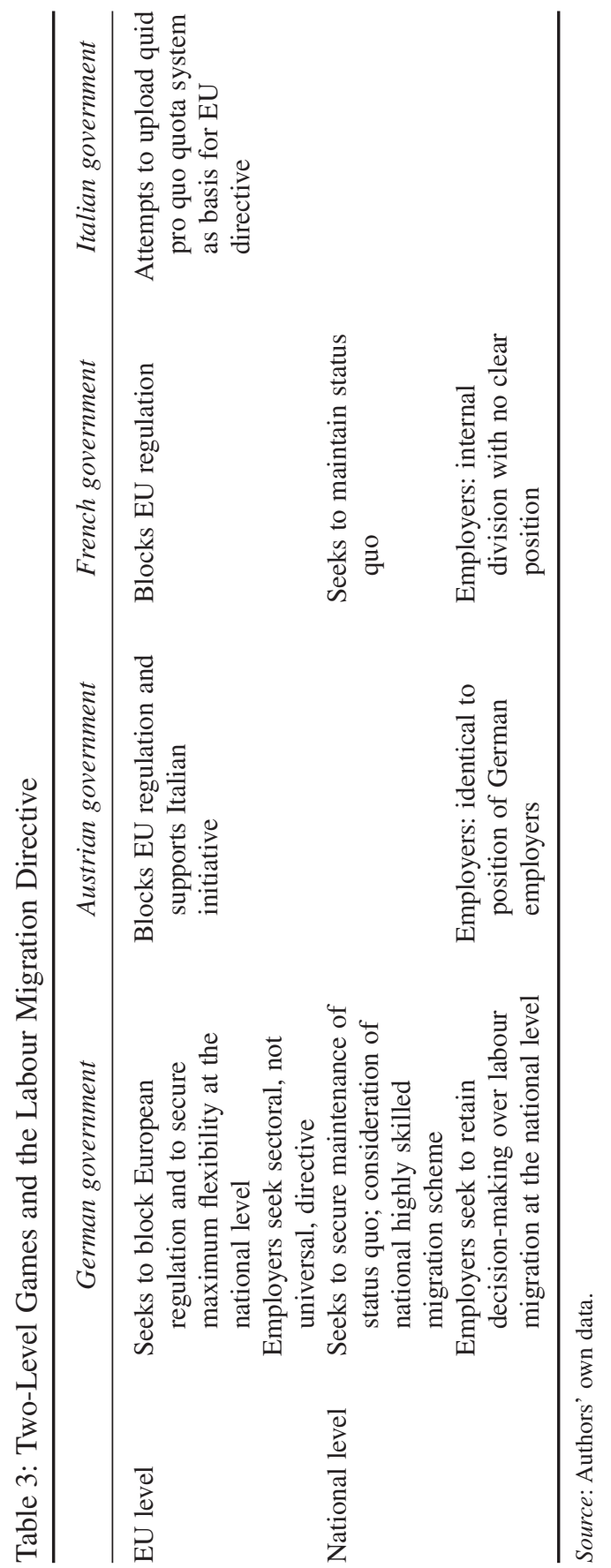


Commission interference into quantitative aspects of migration regulation. UNICE (2005, p. 2) supported a 'horizontal framework covering all categories of economic migrants with more favourable provisions for trainees, intra-corporate transferees, contract service, suppliers, business visitors, seasonal workers'. This is precisely the direction into which the Commission's activity then headed.

The draft directive received formal reading during repeated meetings of the Council throughout the first half of 2002, but it became obvious early on that neither the Germans nor the Austrians were prepared to retreat, while the other delegates displayed no great enthusiasm either, despite the remarkable decision of Ireland (but not the UK) to 'opt in'. By summer 2002, it was clear that no agreement was forthcoming. In light of the sustained resistance, the Commission officially withdrew the proposal on 17 March 2003.

This was not quite the end of it, however. Remarkably, the Italian Presidency revived negotiations by suggesting a common EU labour migration approach using the Italian model of economic migration quotas as a blueprint, based on co-operation by third countries regarding deportations and migration flow detainment. ${ }^{18}$ The proposal was submitted during the informal gathering of the ministers of interior in Rome on 12 and 13 September 2003, ${ }^{19}$ it being suggested that these quotas were used as a tool in negotiations, while placating concerns over subsidiarity by leaving the determination of the quota size to the authority of Member States (Bulletin Quotidien Europe 8539, 11 September 2003; 8541, 13 September 2003). The Commission and the Spanish and Austrian governments welcomed this initiative, but once again the Germans were not convinced (FAZ, 13 September 2003) and neither were the French. During the Thessaloniki Council meeting on 19-20 June 2003, President Chirac emphasized that 'the position of France, Germany, and a certain number of other countries is, a priori, hostile towards the very system of quotas' (Sénat, 2005, p. 34).

Not easily frustrated, the Commission issued a new communication on 3 June 2003 (COM 2003/336 final), in which it strongly emphasized the economic and demographic importance of immigration. In the December 2004 Hague programme outlining future policy until 2010, additional reference was made to 'a policy plan on legal migration, including admission procedures capable of responding promptly to fluctuating demands for migrant labour in the labour market' so as to facilitate a 'knowledge-based economy in Europe, in advancing economic development, and thus contributing to the

\footnotetext{
${ }^{18}$ Interview with senior official at Italian Ministry of Interior Affairs, Rome (henceforth ITA-GOV-1). ${ }^{19}$ ITA-GOV-1.
} 
implementation of the Lisbon strategy'. National reservations entered the document, reflected in the commitment to ensure that 'the determination of volumes of admission of labour migrants is a competence of the Member States' (Conseil européen, 2005).

On 11 January 2005 the Commission presented its Green Paper 'on an EU Approach to Managing Economic Migration' (COM (2004) 811 final). In its introduction, the same arguments are being rehearsed as in previous Commission documents: economic migrants are required in light of demographic developments and also 'in light of the implications [. . . ] on competitiveness'. Conceding defeat, the right to set quantitative targets is clearly allotted to the Member States as 'the Commission has taken into account the reservations and concerns expressed by the Member States during the discussion of the 2001 proposal'.

The Green Paper sets out three options for future discussion: first, to introduce a 'horizontal approach' on the conditions of entry and residence; second, and less ambitiously, to introduce a series of sectoral regulations similar to the ones on students (COM (2002) 548 and researchers (COM (2004) 178)), focusing, for example, on seasonal workers and intra-company transferees; and third, a form of EU Green Card is proposed, through the establishment of a common fast-track procedure for specific labour and skills shortages. This Green Paper solicited more than 160 responses from NGOs, trade unions, employer and business associations, governments, academics and other individuals, culminating in a public hearing on 14 June 2005. On 2 June, ministers debated the Green Paper, demonstrating a willingness to work towards a common framework, but simultaneously finding no consensus as to whether communautarization was necessary on minimum admission standards and 'fast-track' admission, and whether admission should be linked to specific qualitative or quantitative shortages. Opinions on the former point remained divided. The responses from the national governments suggest that the old concerns resurfaced (Bundesregierung, 2005; UK Government, 2005; Sénat, 2005).

The Commission presented the promised policy plan on legal migration on 21 December 2005 (Memo 05/494). Given vociferous opposition at first and continued scepticism notwithstanding some rhetorical overtures, it focused on measures unlikely to encounter much resistance. Thus, the second option proposed in the Green Paper is pursued by promising to elaborate specific directives on the following categories: highly skilled and seasonal workers, intra-corporate transferees and remunerated interns and trainees. This appears to constitute terrain where common ground can be found. The evidently more thorny and ambitious path of elaborating general regulation concerning the procedures and conditions for admission of 
immigrants has been abandoned. On 23 October 2007, the Commission proposed a 'Blue Card', entailing a two-year work and residency permit, valid for the entire EU for highly skilled economic migrants (COM (2007) 637). However, reflecting past conflicts, labour market access will continue to be regulated by national authorities.

The opposition to EU activity was partly fuelled by the actions of employer associations at the national level. Most strongly opposed were German employers. Regulatory power over such a sensitive policy domain escaping the national arena would diminish BDA influence. BDA "very clearly' communicated its position to the Ministry of Interior. ${ }^{20} \mathrm{~A}$ particular worry was an excessively broad European 'one size fits all' policy that would not permit the national 'fine tuning' of desired skill profiles (BDA, 2005) and thus jeopardize the exclusive focus on highly skilled migrants that BDA lobbied for as the basis for national legislation. Austrian employers shared this concern, while there was significant sectoral division within French employer association MEDEF impeding a successful lobbying campaign. ${ }^{21}$

\section{Conclusions}

Europeanization involves embattled political games played out in multiple arenas. Governments attempt to maximize room for national manoeuvre and defend national regulation, delaying EU regulation or suggesting their own regulation ideas as blueprints. In the migration and asylum policy domain, these efforts are remarkably successful. Governments play two-level games. At the national level, non-state actors engage interior ministries, attempting to shape the national negotiation position. However, unless such actors can build successful coalitions, as German NGOs with the Green Party, at the time part of the coalition government, and as German employers did by lobbying a Ministry of Interior already sceptical of communitarian efforts regarding economic migration, their influence appears limited Given the degree of politicization and contestation policy, the influence of non-state actors is thus strongly conditioned by coalition-building capacity. In line with an early contribution to the Europeanization literature (Andersen and Eliassen, 1993), the process needs to be conceptualized as unfolding over several tiers, spawning protracted political battles not only at the EU level, but also domestically, akin to 'second image reversed' processes (Gourevitch, 1978). The exact contours and content of the national interest remain heavily embattled

${ }^{20}$ DE-GOV-1; DE-BUS-1.

${ }^{21}$ FR-GOV-1. 
territory despite governments' attempts to ward off the influence of non-state actors.

Correspondence:

George Menz

Reader in Political Economy

Department of Politics

Goldsmiths College

University of London

New Cross

London, SE14 6NW, UK

email g.menz@gold.ac.uk

\section{References}

Amnesty International (2002) Stellungnahme von amnesty international zu dem [ . . ] Zuwanderungsgesetz BT 14/7387 (Bonn: Amnesty International).

Amnesty International, Arbeiterwohlfahrt, Arbeitsgemeinschaft Ausländer- and Asylrecht, Deutscher Caritasverband, Pro Asyl (2007) Geminsame Stellungnahme zu dem Entwurf des Gesetzes zur Umsetzung aufenthalts- und asylrechtlicher Richtlinien der Europäischen Union in der Fassung vom 8. Februar 2007 (Berlin: Amnesty International).

Andersen, S. and Eliassen, K. (1993) The Europification of National Policy-Making (London: Sage).

Bache, I. (2008) Europeanization and Multi-level Governance: Cohesion Policy in the European Union and Britain (Lanham, MD: Rowman \& Littlefield).

BDA (2005) Gemeinsame Stellungnahme des BDA, BDI und BDH zum Grünbuch der Europaeischen Kommission zur Verwaltung der Witschaftsmigration (Berlin: BDA).

Biffl, G. (2005) 'Zur Niederlassung von Ausländern und Ausländerinnen in Österreich'. Östereichisches Institus für Wirtschaftsforschung (WIFO) 2005/214 (Vienna: WIFO).

Börzel, T. (2002) 'Member State Responses to Europeanization'. JCMS, Vol. 40, No. 2, pp. 193-214.

Börzel, T. and Risse, T. (2000) 'When Europe Hits Home: Europeanization and Domestic Change'. European Integration Online Papers (EIOP), Vol. 4, No. 15. Available at «eiop.or.at/eiop/texte/2000-015a.htm».

Börzel, T. and Risse, T. (2003) 'Conceptualising the Domestic Impact of Europe'. In Featherstone, K. and Radaelli, C. (eds) The Politics of Europeanization (Oxford/ New York: Oxford University Press).

Bundesregierung (2005) Stellungnahme der Bundesregierung zum Grünbuch über ein EU-Konzept zur Verwaltung der Wirtschaftsmigration (Berlin: Bundesregierung). 
Conseil européen (2005) La commission européenne lance une débat public sur les migrations économiques (Brussels: Conseil européen). Available at «http:// europa.eu/rapid/pressReleasesAction.do?reference=IP/05/16\&format=HTML\& aged $=1 \&$ language $=$ FR \& guiLanguage $=$ fr $\gg$.

COORDEUROP (2003a) Letter to the President of the European Parliament, 6 October.

COORDEUROP (2003b) Letter to the Members of the EP Legal Affairs and Internal Market Committee, 10 November.

Cornelius, W., Martin, P.L. and Hollifield, J.F. (eds) (2004) Controlling Immigration: A Global Perspective (Stanford, CA: Stanford University Press).

Cowles, M.G., Caporaso, J. and Risse, T. (2001) 'Europeanization and Domestic Change: An Introduction'. In Transforming Europe: Europeanization and Domestic Political Change (Ithaca, NY: Cornell University Press).

Duchrow, V. (2004) 'Flüchtlingsrecht und Zuwanderungsgesetz unter Berücksichtigung der sog. Qualifikationsrichtlinie'. Zeitschrift für Ausländerrecht und Ausländerpolitik, Vol. 10, pp. 339-46.

Evrensel, A. and Höbart, C. (2004) Migration im Österreichischen Roten Kreuz: Gesamtstudie (Vienna: Ludwig Boltzmann Institut für Menschenrechte).

Faist, T. and Ette, A. (eds) (2007) The Europeanization of National Policies and Politics of Immigration (Basingstoke: Palgrave Macmillan).

Favell, A. (1998) 'The Europeanisation of Immigration Politics'. European Integration Online Papers (EIOP), Vol. 2, No. 10. Available at «eiop.or.at/eiop/texte/ 1998-010a.htm».

Fischer, A., Nicolet, S. and Sciarini, P. (2002) 'Europeanisation of a Non-EU Country: The Case of Swiss Immigration Policy'. West European Politics, Vol. 25, No. 4, pp.143-70.

Franz, M. (2006) Familienzusammenführung in der Einwanderungspolitik der Europäischen Union, IMIS Beiträge, Vol. 30 (Osnabrück: Universität Osnabück).

Geddes, A. (2000) 'Lobbying for Migrant Inclusion in the European Union: New Opportunities for Transnational Advocacy?' Journal of European Public Policy, Vol. 7, No. 4, pp. 632-49.

Geddes, A. and Guiraudon, V. (2004) 'The Emergence of a European Union Policy Paradigm amidst Contrasting National Models: Britain, France and EU Anti-discrimination Policy'. West European Politics, Vol. 27, No. 2, pp. 334-53.

Goetz, K. (2002) 'Four Worlds of Europeanization'. Paper presented at the Workshop 'Europeanisation and National Political Institutions' at the ECPR Joint Session of Workshops, Torino.

Goetz, K. and Hix, S. (eds) (2001) Europeanised Politics: European Integration and National Political Systems (London: Frank Cass).

Gourevitch, P. (1978) 'The Second Image Reversed: The International Sources of Domestic Politics'. International Organization, Vol. 32, pp. 881-911.

Gourevitch, P. (1996) 'Squaring the Circle: The Domestic Sources of International Co-operation', International Organization, Vol. 50, No. 2, pp. 349-73. 
Graziano, P. and Vink, M. (eds) (2007) Europeanization: New Research Agendas (Basingstoke: Palgrave Macmillan).

Green, S. (2004) The Politics of Exclusion: Institutions and Immigration Policy in Contemporary Germany (Manchester/New York: Manchester University Press).

Groenendijk, K. (2004a) 'Legal Concepts of Integration in EU Migration Law'. European Journal of Migration and Law, Vol. 6, No. 2, pp. 1388-64X.

Groenendijk, K. (2004b) 'Rechtliche Konzepte der Integration im EGMigrationsrecht'. Zeitschrift für Ausländerrecht und Ausländerpolitik, Vol. 4, pp. 123-9.

Guiraudon, V. (2000) 'European Integration and Migration Policy: Vertical PolicyMaking as Venue Shopping'. JCMS, Vol. 38, No. 2, pp. 249-69.

Hansen, R. (2002) 'Globalization, Embedded Realism and Path Dependence: The Other Immigrants to Europe'. Comparative Political Studies, Vol. 35, No. 3, pp. 259-83.

Hauschild, C. (2003) 'Neues europäisches Einwanderungsrecht: Das Recht auf Familienzusammenführung'. Zeitschrift für Ausländerrecht und Ausländerpolitik, Vol. 23, No. 8, pp. 266-73.

Héritier, A. (1996) 'The Accommodation of Diversity in European Policy-Making and Its Outcomes: Regulatory Policy as Patchwork'. Journal of European Public Policy, Vol. 3, No. 2, pp. 149-67.

Héritier, A., Kerwer, D., Knill, C., Lehmkuhl, D., Teutsch, M. and Douillet, A.-C. (eds) (2001) Differential Europe: The European Union Impact on National Policymaking (Lanham, MD: Rowman \& Littlefield).

Jordan, A. (2002) The Europeanization of British Environmental Policy: A Departmental Perspective (Basingstoke: Palgrave).

Jordan, A. and Liefferink, D. (eds) (2004) Environmental Policy in Europe: The Europeanization of National Environmental Policy (London: Routledge).

Keohane, R. and Milner, H. (1996) 'Internationalization and Domestic Politics: An Introduction'. In Internalization and Domestic Politics (Cambridge: Cambridge University Press).

Knill, C. and Lehmkuhl, D. (1999) 'How Europe Matters: Different Mechanisms of Europeanization'. European Integration Online Papers (EioP), Vol. 3, No. 7. Available at «eiop.or.at/eiop/texte/1999-007a.htm».

Knill, C. and Lehmkuhl, D. (2002) 'The National Impact of European Union Regulatory Policy: Three Europeanization Mechanisms'. European Journal of Political Research, Vol. 41, No. 2, pp. 255-80.

Ladrech, R. (1994) 'Europeanization of Domestic Politics and Institutions: The Case of France'. JCMS, Vol. 32, No. 1, pp. 69-88.

Marks, G. and Hooghe, L. (2004) 'Contrasting Visions of Multi-level Governance. In Bache, I. and Flinders, M. (eds) Multi-level Governance (Oxford: Oxford University Press).

Menz, G. (2008) The Political Economy of Managed Migration (Oxford: Oxford University Press). 
Messina, A. (2007) The Logics and Politics of Post-WW II Migration to Western Europe (Cambridge/New York: Cambridge University Press).

Milner, H. (1992) 'International Theories of Co-operation of Nations: A Review Essay'. World Politics, Vol. 44, No. 3, pp. 466-96.

Milner, H. (1997) Interests, Institutions and Information: Domestic Politics and International Relations (Princeton, NJ: Princeton University Press).

Olsen, J. (2002) 'The Many Faces of Europeanization'. JCMS, Vol. 40, No. 5, pp. 921-52.

Putnam, R. (1988) 'Diplomacy and Domestic Politics: The Logic of Two-Level Games'. International Organization, Vol. 42, No. 3, pp. 427-60.

ProAsyl (2004) Europäische Asylpolitik: Minimale Standards - Maximale Abschottung (Frankfurt: ProAsyl).

Radaelli, C. (2000) 'Whither Europeanization? Concept Stretching and Substantive Change'. European Integration Online Papers (Eiop), Vol. 4, No. 8. Available at «eiop.or.at/eiop/texte/2000-008.htm».

Radaelli, C. (2003) 'The Europeanization of Public Policy'. In Featherstone, K. and Radaelli, C. (eds) The Politics of Europeanization (Oxford/New York: Oxford University Press).

Rogowski, R. (1989) Commerce and Coalitions (Princeton, NJ: Princeton University Press).

Schibel, Y. (2004) Monitoring and Influencing the Transposition of EU Immigration Law: The Family Reunion and Long Term Residents Directive. Occasional Paper (Brussels: Migration Policy Group).

Schmidt, V.A. (2006) 'Procedural Democracy in the EU: The Europeanization of National and Sectoral Policy-Making Processes'. Journal of European Public Policy, Vol. 13, No. 5, pp. 670-91.

Sénat (2005) 'Rapport d'Information fait au nom de la délégation pour l'Union européenne sur la politique européenne d'immigration'. Session ordinaire 20042005, No. 385 (Paris: Sénat).

Snyder, G. (1977) Conflict among Nations: Bargaining, Decision-Making and System Structure in International Crisis (Princeton, NJ: Princeton University Press).

Uçarer, E. and Puchala, D. (eds) (1997) Immigration into Western Societies (Washington, DC: Pinter).

UK Government (2005) European Commission's Green Paper on an EU Approach to Managing Economic Migration: The Response of the United Kingdom (London: UK Government).

UNHCR (2002) Stellungnahme zum Zuwanderungsgesetz vom 14.1.2002, BT-Drucksache 14/6741 (Berlin: UNHCR).

UNICE (2005) Commission Green Paper on an EU Approach to Managing Economic Migration: UNICE Response (Brussels: UNICE).

Vink, M. (2005) Limits of European Citizenship: European Integration and Domestic Immigration Politics (Basingstoke: Palgrave Macmillan).

Wallace, H. (2000) 'Europeanisation and Globalisation'. New Political Economy, Vol. 5, No. 3, pp. 369-82. 